\title{
Strategy for the Implementation of Blended Learning at MTs Muhammadiyah 1 Taman [Strategi Penerapan Blended Learning Di MTs Muhammadiyah 1 Taman]
}

\author{
Shafa Ayu Faramida*, Muhlasin Amrullah \\ \{ Shafafaramida@gmail.com, muhlasin1@umsida.ac.id\} \\ Fakultas Psikologi dan Ilmu Pendidikan,Universitas Muhammadiyah Sidoarjo, Indonesia
}

\begin{abstract}
This research is about what learning strategies were used during the Covid-19 pandemic at MTS Muhammadiyah 1 Taman. The Covid-19 pandemic has disrupted the conventional learning process. With that, this research was conducted to determine the learning strategies carried out at the school. This research use desciptive qualitative approach. The purpose of the research was to obtain an overview of the implementation of online learning at MTS Muhammadiyah 1 Taman as an effort to reduce the spread of the Covid-19 virus. The data source used is the primary data source. he informant in this is the Principal of Madrasah Mts Muhammadiyah 1 Taman. Data collection techniques used include interviews, observation, and documentation. The results of this study indicate that the learning strategy during the Covid-19 pandemic uses the Blendid Learning strategy which is carried out face-to-face and online. With this strategy, students can enter school on a predetermined schedule in turn. This strategy is very efficient because in addition to students being able to do face-to-face learning with the teacher in the classroom, they can also access the material provided online wherever they are. When students do not understand the material provided, they can discuss it in person in class or online. Of course, this is very beneficial for both educators and students, because learning will be very comfortable and more effective.
\end{abstract}

Keywords: Learning strategy, Pandemi Covid-19, Blended Learning, Junior High School.

\begin{abstract}
Abstrak. Penelitian ini tentang strategi pembelajaran apa yang digunakan pada saat pandemi Covid-19 di MTS Muhammadiyah 1 Taman. Pandemi Covid-19 ini telah mengganggu proses pembelajaran secara konvensional. Dengan itu penelitian ini dilakukan guna mengetahui strategi pembelajaran yang dilakukan di sekolah tersebut. Penelitian ini menggunakan pendekatan deskriptif kualitatif. Tujuan dari penelitian adalah untuk memperoleh gambaran pelaksanaan pembelajaran daring di MTS Muhammadiyah 1 Taman sebagai upaya menekan penyebaran virus Covid-19. Sumber data yang digunakan adalah sumber data primer. Informan dalam ini adalah Kepala Madrasah Mts Muhammadiyah 1 Taman. Tekhnik pengumpulan data digunakan meliputi wawancara, observasi, dan dokumentasi. Hasil penelitian ini menunjukkan bahwa strategi pembelajaran pada masa pandemi Covid - 19 dengan menggunakan startegi Blendid Learning yang dilakukan secara tatap muka dan daring. Dengan strategi tersebut, siswa dapat masuk sekolah dengan jadwal yang sudah ditentukan secara bergantian. Startegi ini sangatlah efesien karena selain murid bisa melakukan pembelajaran tatap muka dengan guru didalam kelas, mereka juga bisa mengakses materi yang diberikan secara online di manapun mereka berada. Ketika murid kurang mengerti dengan materi yang diberikan, mereka bisa mendiskusikannya secara langsung didalam kelas ataupun secara online. Tentunya ini sangat menguntungkan bagi pihak pendidik dan siswa, karena pembelajaran yang dilakukan akan sangat nyaman dan lebih efektif.
\end{abstract}


Kata Kunci: Strategi Pembelajaran, Pandemi Covid-19, Blended Learning, MTs/SMP

\section{Pendahuluan}

Pendidikan adalah suatu proses untuk menciptakan dan mengembangkan potensi peserta didik yang aktif. Menurut Azhari menyatakan bahwa pendidikan menentukan perekambangan dan perwujudan sumber daya manusia khususnya pembangunan bangsa dan negara pendidikan memiliki peranan yang penting dalam membentuk sumber daya manusia yang cerdas, cakap kreatif, beriman, dan berakhlak mulia. Suatu negara bisa dikatakan negara maju apabila mereka mampu menciptakan pendidikan yang berkualitas. Karena, perkembangan suatu bangsa dapat dilihat dari bagaimana hasil perkembangan pendidikan tersebut. Sekolah merupakan salah satu tempat yang efektif dalam proses belajar mengajar. Sekolah termasuk lembaga formal yang bertujuan untuk mendidik semua warga sekolah. Proses belajar mengajar yang dilakukan pada dasarnya dapat membentuk karakter peserta didik dan mengarahkan siswa agar proses pembelajaran dapat belajar dengan semestinya. Agar kegiatan dapat berjalan efektif maka, diperlukannya tenaga pendidik yang dengan setulus hati memberikan ilmunya kepada siswa sesuai kemampuan yang telah dimiliki. Karena, semakin baik kualitas pendidikan akan semakin baik pula sekolahnya dan juga akan menciptakan sesorang yang berkualitas baik pula. [1]

Namun, sangat disayangkan pada awal tahun 2020, dunia dibuat kaget dengan keberadaan sautu virus baru bernama Corona. Virus yang awal mulanya menyerang negara Cina tepatnya di Wuhan, kemudian merambah ke seluruh dunia salah satunya Indonesia. Pandemi Covid-19 ini berdampak pada berbagai bidang salah satunya bidang pendidikan. Untuk memutus rantai Pandemi Covid-19, pemerintah membuat kebijakan untuk bidang pendidikan yakni dengan melakukan kegiatan belajar mengajar secara online atau daring. Bukan hanya berlaku bagi siswa saja, pemerintah juga memberikan kebijakan pada warga agar social distancing, bekerja dan beribadah di dalam rumah, serta pembatasan sosial berskala besar atau PSBB. Sistem pembelajaran daring ini merupakan pembelajaran tanpa tatap muka secara langsung antara dosen/guru dan mahasiswa/siswa, tetapi dilakukan melalui online dengan menggunakan jaringan internet. Pandemi Covid-19 menjadikan seseorang harus menjauh dari kerumunan. Karena itu, hampir seluruh negara melakukan kegiatan virtual untuk menggantikan kegaiatan tatap muka. Namun, datangnya pandemi yang secara tiba-tiba ini tentu membawa problem yang tidak bisa diremehkan.[2] Berdasarkan paparan diatas maka peneliti akan melakukan observasi dan wawancara untuk mengungkap bagaimana proses pembelajaran jarak jauh atau strategi apa yang dilakukan di MTs Muhammadiyah 1 Taman selama masa pandemi Covid-19. Sekolah juga telah mengimplementasikan pembelajaran jarak jauh karena selain utnuk mengurangi penyebaran virus, pembelajaran harus tetap dilaksanakan agar peserta didik tetap dapat memperoleh materi pelajaran selagi masa pandemi tengah berlangsung.

\section{Metode Penelitian}

Hasil penelitian diatas yang berisikan tentang strategi pembelajaran di MTS Muhammadiyah 1 Taman pada masa pandemi Covid-19 menggunakan pendekatan deskriptif kualitatif. Pendekatan kualitatif ini bertujuan untuk mendeskripsikan pelaksanaan pembelajaran pada masa pandemi Covid-19 di MTs Muhammadiyah 1 Taman. Menggunakan pendekatan kualitatif dianggap sangat efektif dalam peninjauan di sekolah tersebut karena, dengan pendekatan ini dapat menafsirkan dan memguaraikan data yang bersangkutan dengan situasi yang sedang terjadi, sikap serta pandangan di lingkungan masyarakat, dan perbedaan antara fakta yang sedang ada serta pengaruhnya terhadap suatu kondisi. Subjek dalam penelitian ini 
yaitu Kepala Madrasah MTs Muhammadiyah 1 Taman. Kepala madrasah tersebut merupakan kunci dalam penelitian ini. Sumber data yang digunakan dalam penelitian ini yaitu menggunakan sumber data primer. Sumber data primer dalam penelitian diperoleh secara langung dari informan melalui wawancara dan observasi mengenai strategi pembelajaran pada masa pandemi Covid-19. Hasil dari wawancara observasi dan dokumentasi dianalisis dan diolah menjadi data interaktif.

Tekhnik penelitian yang dilakukan antara lain dengan observasi, wawancara dan dokumentasi. Obervasi adalah metode pengumpulan data dimana peneliti mencatat informasi sebagaiman yang mereka saksikan selama penelitian W. Gulo [3]. Peneliti berada di tempat itu dengan mengamati secara langsung dan mendapatlan bukti-bukti yang valid. Tekhnik wawancara dilakukan oleh dua pihak yaitu pewawancara (yang mengajukan pertanyaan) dan narasumber (yang memberikan jawaban). Tekhnik ini bertujuan untuk menggali sumber-sumber informasi yang ada dalam suatu tempat tersebut. Tekhnik terakhir yaitu tekhnik dokumentasi yang bertujuang untuk mendukung sumber data tersebut.

\section{Hasil dan Pembahasan}

MTs Muhammadiyah 1 Taman bediri pada tahun 1980 an. Sekolah tersebut berada dalam naungan Pimpinan Cabang Muhammadiyah Sepanjang yang mulai dikembangkan ditahun itu. Di awal pembentukan sekolah tersebut hanya mempunyai 10 siswa dan mencoba bertahan hingga di tahun ke 5 berdirinya sekolah tersebut penurunan perolehan siswa semakin turun dan dapat dihitung jari jumlahnya. Adanya peristiwa tersebut membuat Pimpinan Cabang Muhammadiyah (PCM) turun tangan dengan cara mengambil alih sekolah dan merelokasi dari Sambiroto ke daerah Sepanjang. Namun hal itu tidak disetujui oleh masyarakat sekitar. [4] Jauh sebelum berdirinya MTs Muhammadiyah 1 Taman, sudah terdapat SMP Muhammadiyah 2 Fillial Sambiroto. Dengan peristiwa yang sedang dialami MTs Muhammadiyah 1 Taman, tepat di tahun 1993 dibawah kepemimpinan Ustad di SMP Muhammadiyah 2 Fillial Sambiroto mengajukan perubahan status dari SMP ke MTs. Pengajuan perubahan status sekolah terebut disetujui yang dari awalnya dikenal sebagai SMP Muhammadiyah 2 Fillial Sambiroto menjadi satu dengan MTs Muhammadiyah 1 Taman hingga sampai pada saat ini. Kini, nama besar MTs Muhammadiyah 1 Taman semakin dikenal dan dicintai masyarakat.

Dari hasil penelitian yang dilakukan di MTs Muhammadiyah 1 Taman, untuk saat ini memberlakukan strategi pembelajaran secara daring sesuai dari kebijakan pemerintah. Strategi yang digunakan menggunakan strategi Blended Learning. Blended learning merupakan kegiatan perpaduan antara pembelajaran tatap muka secara terbatas dengan pembelajaran daring yang melalui aplikasi. Semler menegaskan bahwa: "Blendid learning mengkombinasikan aspek terbaik dari pembelajaran online, aktivitas tatap muka terstruktur, dan praktek dunia nyata. Sistem pembelajaran online, latihan di kelas, dan pengalaman on the job akan memberikan pengalaman berharga bagi diri mereka. Blended learning menggunakan pendekatan memberdayakan berbagai sumber informasi yang lain. [4]

Moebs \& Weibelzahl mendefinisikan Blended Learning sebagai pencampuran antara online dan pertemuan tatap muka (face-to-face meeting) dalam satu aktivitas pembelajaran yang terintegrasi. Pembelajaran tersebut dilakukan melalui beberapa fitur-fitur yang sudah disediakan oleh pihak sekolah. Salah satu apikasi yang digunakan di Mts Muhammadiyah 1 Taman adalah aplikasi ETMUDO. Aplikasi ETMUDO ini adalah salah satu dari banyaknya fitur-fitur pembelajaran lainnya seperti Goggle classroom, Zoom, yang menjadi wadah agar pembelajaran dapat berjalan baik dan lancar. Para guru dapat memberikan materi melalui aplikasi tersebut dan secara langsung siswa dapat mengakses materi-materi yang telah diberikan oleh gurunya. Secara 
umum karakteristik Blended Learning sebagai berikut: 1) Pembelajaran yang menggabungkan berbagai cara penyampaian, model pengajaran, gaya pembelajaran, serta berbagai media berbasis tekhnologi yang beragam; 2) Sebagai sebuah kombinasi pengajaran langsung (face-toface), belajar mandiri, dan belajar mandiri via online; 3) Pengajar dan orangtua peserta belajar memiliki peran yang sama penting, pengajar sebagai fasilitator, dan orangtua sebagai pendukung. [5];[6]

Sesuai dengan perkembangan terutama di daerah Sidoarjo yang sudah bisa dikatakan sebagai zona hijau, beberapa sekolah mulai mencoba melakukan pembelajaran secara tatap muka. Pihak Kementrian menyampaikan pada bulan Januari sekolah dapat diaktifkan kembali sesuai dengan kondisi daerahnya masing-masing. Kapubaten Sidoarjo menjadi salah satu daerah yang terpilih. Beberapa sekolah dijadikan masa percobaan pembelajaran tatap muka dengan mengikuti protokol kesehatan. Meskipun MTs Muhammadiyah 1 Taman tidak menjadi salah satu sekolah yang terpilih dalam percobaan tersebut tetapi, sesuai dari hasil rapat yang telah dilakukan sekolah MTs Muhammadiyah 1 Taman akan melakukan kegiatan pembelajaran tatap muka terbatas pada bulan Juli. Percobaan pertama yang dilakukan pada saat awal bulan puasa dengan skema kelas VII dan kelas VIII masing-masing masuk kelas selama dua hari dan di dalam satu kelas hanya diisi sekitar 15 siswa. Tabel 1

Tabel 1. Jadwal Masuk Kelas Seminggu Sebelum Puasa

\begin{tabular}{llllll}
\hline Senin & Selasa & Rabu & Kamis & Jumat & Sabtu \\
& & & & & \\
\hline Kelas & Kelas & Kelas & Kelas & Libur & Libur \\
VII & VII & VIII & VIII & & \\
\hline
\end{tabular}

Setelah dilakuannya masa percobaaan di awal bulan puasa dengan mengikuti aturan protokol kesehatan, akhirnya sekolah memutuskan untuk memberlakukan startegi tersebut dan merombak jadwal sebelumnya. Pada minggu selanjutnya, kelas VII mengikuti kegiatan pembelajaran tatap muka dikelas dari hari senin hingga jumat dan kelas VIII menggunakan kegiatan pembelajaran secara daring. Begitu seterusnya di minggu-minggu selanjutnya terjadi pergantian jadwal tatap muka selama seminggu. Strategi ini sudah berjalan selama tiga minggu ini dan menurut Pimpinan serta para guru disana mengatakan bahwa strategi tersebut sudah sangatlah cukup efektif di masa pandemi Covid-19 ini.

\section{Kesimpulan}

Strategi pembelajaran yang diterapkan pada masa pandemi Covid-19 di MTs Muhammadiyah 1 Taman menggunakan strategi Blended Learning. Startegi ini sangatlah efesien karena selain murid bisa melakukan pembelajaran tatap muka dengan guru didalam kelas, mereka juga bisa mengakses materi yang diberikan secara online di manapun mereka berada. Ketika murid kurang mengerti dengan materi yang diberikan, mereka bisa mendiskusikannya secara langsung didalam kelas ataupun secara online. Tentunya ini sangat menguntungkan bagi pihak pendidik dan siswa, karena pembelajaran yang dilakukan akan sangat nyaman dan lebih efektif.

\section{Ucapan Terima Kasih}


Dengan terselesaikannya penelitian ini, penulis mengucapkan terima kasih yang sedalamdalamnya kepada Allah SWT atas limpahan karunia dan hidayahnya sehingga penulis dapat melaksanakan penelitian dan meyelesaikan penelitian. Bapak Dosen Muhlasin Amrullah, M.Pd.I selaku dosen kami atas bimbingan, arahan, dan koreksinya selama penyusunan dan penyusunan penelitian. Bapak dan Ibu guru MTs Muhammadiyan 1 Taman, yang telah memberikan izin dan bersedia untuk diwawancarai. Teman-teman yang saling membantu dan mendukung dalam mengerjakan penelitian ini..

\section{References}

[1] Siahaan, Matdio, "Dampak Pandemi Covid-19 Terhadap Dunia Pendidikan,” jurnal kajian ilmiah, vol. 1, no. 3, tahun. [2019]. Available: http://repository.ubharajaya.ac.id/4842/

[2] Kemendikbud. (2020). Pedoman penyelenggaraan pembelajaran pada tahun ajaran dan tahun akademik baru pada masa pandemi Covid - 19. https://dikti.kemdikbud.go.id

[3] Gulo, W. 2002. Metodologi Penelitian. Jakarta: Grasindo Indonesia. Goggle Cendekia.

[4] Semler, S. 2005. Use Blended learning to Increase Learner Engagement and Reduce Training Cost. (Online). (http://www.learningsim.com/content/lsnews/ blended_learning1.html, diakses tanggal 1 Juni2013)

[5] Moebs, S. \& Weibelzahl, S. 2006. Towards a good mix in Blended learningfor small and medium sized enterprises. Outline of a Delphi Study. Proceedings of the Workshop on Blended learning and SMEs held in conjuction with the 1st European Conference on Technology Enhancing Learning Crete, Greece, pp 1-6.

[6] Sejarah berdirinya MTs Muhammadiyah 1 Taman. https://mtsmuhita.sch.id. 